\title{
CALUX Bioassay analysis of PCDD/Fs and dioxin- like PCBs in Bovine milk and Municipal dumping site Ash samples from Indian environment
}

\section{Murugasamy Mayilsamy}

Hiyoshi India private limited

\section{Seethappan Sangeetha}

Bharathidasan University

\section{Masafumi Nakamura}

Hiyoshi Corporation

\section{Shunkei Ko}

Hiyoshi Corporation

Muthusamy Govarthanan

Kyungpook National University

Vimalkumar Krishnamoorthi ( Vimalkumar.Krishnamoorthi@nyulangone.org )

NYU Langone Medical Center: NYU Langone Health https://orcid.org/0000-0002-2278-1480

\section{Research Article}

Keywords: PCDD/Fs, DL-PCBs, Bovine milk, Municipal dump ash, CALUX Assay

Posted Date: April 26th, 2021

DOI: https://doi.org/10.21203/rs.3.rs-356344/v1

License: (c) (i) This work is licensed under a Creative Commons Attribution 4.0 International License. Read Full License 


\section{Abstract}

This study showed the distribution of PCDD/Fs and DL-PCBs in bovine milk and ash samples collected from urban and rural areas of south Tamil Nadu and one milk sample from Japan. Around 25 bovine milk samples and 16 ash samples were collected accordingly. The total TEQ for PCDD/Fs and DL-PCBs were ranged from 0.028 to $7.331 \mathrm{pg}$ TEQ/g fat. Some of the districts were showed higher PCDD/Fs and DLPCBs concentration in milk and ash samples. Further, BM14 (7.331 pg-TEQ/g fat) and BM21 (6.406 pg$\mathrm{TEQ} / \mathrm{g}$ fat) area exceed level of PCDD/Fs and DL-PCBs than WHO regulation limits (6 pg-TEQ/g fat). Likewise, BM3, BM8, and BM14 areas showed higher milk contamination by dioxins, which exceed the WHO regulation limit (3pg-TEQ/g fat).

Similarly, the total TEQ for PCDD/Fs and DL-PCBs in ash samples was ranged from 0.02 to $1.2 \mathrm{ng} T E Q / \mathrm{g}$. AS3 (1.2 ng-TEQ/g) and AS11 (1.06 ng-TEQ/g) areas showed higher dioxins and DL-PCBs among the samples. This study provides an overview of dioxins and dioxin-related compounds contamination in bovine milk and ash samples. Further, the CALUX assay method validation has simplifies the monitoring of dioxin contamination in the environment.

\section{Highlights}

- PCDD/Fs and DL-PCBs are the major environmental pollutants released from combustion of waste materials and industries (pesticide and paper manufacturing).

- Bovine milk was contaminated by consumption of contaminated feed and exposed nearby sources (Dioxin producing factories/municipal solid waste dumping sites)

- Bovine milk is the major source for dioxin and dioxin like compounds exposure on humans.

- Ash samples are the sink for accumulate dioxins and related contaminants after combustion or incineration

- Rural areas also polluted by PCDD/Fs and DI-PCBs through dumping of municipal solid wastes.

- Larger cities show exceed level of dioxins and dioxin related compounds than European regulation level (6 pg-TEQ/g fat)

\section{Introduction}

The PCDD/Fs are also known as endocrine disrupting compounds; consist of 75 polychlorinated dibenzop-dioxins and 135 polychlorinated dibenzofurans. Similarly, PCBs are a group of 12 polychlorinated biphenyls with similar chemical and toxicological properties of PCDD/Fs. Dioxin like PCBs are carcinogenic and included in group I (Lauby-Secretan et al. 2013). Both of them are chemically inert and resistant to biodegradation, hence persistent in the environment for long period (Esposito et al. 2010).

PCDD/Fs and PCBs are highly lipophilic in nature and can easily accumulate in the fat tissues and bio magnification. This will leads to severe effects on animals as well as humans and cause adverse effects on environment. PCDD/Fs and PCBs primary source are industrial sectors like metallurgical production, 
paper production, pesticide manufacturing, etc (Esposito et al. 2009, Esposito et al. 2010). For example, bovine milk from Northern Italy is highly contaminated by dioxins and PCBs, due to industrialization and agricultural activities (Bertocchi et al. 2015). Humans are mainly exposed through diet, almost $90 \%$ of human exposure via food. Some literatures illustrate that, milk and dairy products are significant sources for PCBs and dioxins (27.5-49.6\%) in humans (Authority 2012). A higher concentration of dioxins and PCBs had observed in animal origin foodstuffs like milk, meat, fish, and dairy products (Bocio \&Domingo 2005, Kiviranta et al. 2004). The becomes a significant concern among researchers to monitor the dioxins and DL-PCBs in environment. Many techniques are available to measure their concentration in environmental matrices.

The conventional methods (high- resolution mass spectrometry (HRMS/HRGC)) applied to measure dioxins in different samples. This method is high accurate and outstanding reliability of separate the specific chemicals. But the disadvantage of the conventional method is time consuming; it takes 4-6 weeks to obtain the concentration of PCDD/Fs and DL-PCBs in samples. Some of the samples cannot be store for long time like pasteurized milk can only store for approximately $7-10$ days at $4-7^{0} \mathrm{C}$.

The reason to choose CALUX assay was cheaper, rapid and can analysis higher number of samples. This method takes only 3-7 days to obtain the results. CALUX assay used to determine the dioxins directly total toxic equivalency (TEQ) and to measure dioxins in different samples, such as eels, mussels, fish, food stuff (beef, cod liver, and milk), human blood plasma, breast milk, soil, and sediment (Warner et al. 2005) (Hoogenboom et al. 2006). Chou et al. (2008) measured PCDD/Fs in cow's milk by CALUX assay.

Dioxins and related chemicals cause effects on the cells through the aryl hydrocarbon receptor, which is a transcription factor. Activation of aryl hydrocarbon receptor (AhR) by dioxins modifies the gene expressions, involved in the cell growth and differentiation (Cancer 1997). Alterations in the gene expression will leads to various toxic effects. The concentration of dioxins and dioxin like compounds in different samples had quantified by chemically activated luciferase gene expression (CALUX) assay. This is an in vitro bio-analytical tool applied in research and commercial laboratories. CALUX assay is a reporter gene based cell bioassay; the genetically modified cells used for this assay. The cells that contain the luciferase reporter gene, which response to the dioxin and dioxin-like chemicals. This gene expression was induced by binding and activating of the AhR. The luciferase gene expression depended on the time, dose, AhR dependent and chemical specific manner. The amount of induced luciferease activity can measure the concentration of the chemical. The luminescence by chemical converted to bioassay TEQ value by comparing the response against the given dose of chemical and response to 2, 3 , 7, 8- tetrachlorodibenzo- $p$-dioxin (TCDD). CALUX assay used to analyze all AhR active compounds in the extract samples. However, the results interpretation could be complicated compared to chemical analysis because the extracted sample contains a mixture of chemicals (Han et al. 2004). Presence of other contaminants (metals) could affect the CALUX assay readings.

This study's main objective is to determine the dioxins and dioxin like compounds in the Municipal dumping site ash and bovine milk samples using CALUX assay. 


\section{Materials And Methods}

\subsection{Chemical reagents and solvents}

Hexane (for pesticide residue analysis), RPMI 1640 media, 545 celite, D-PBS and Nonane (for dioxin analysis), Ethyl acetate (for pesticide residue analysis), Acetone, Toluene and sulfuric acid, Sodium sulfate and silica gel (for making column).

\subsection{Sample collection}

Bovine milk and Municipal dump ash samples of urban and rural areas were collected (January - April, 2012) from the different urban and rural regions (districts) of South India (Fig. 1). 25 milk samples (150 $\mathrm{ml}$ of Bovine Milk), and 16 ash samples (50 g of Ash sample) were collected in dumping sites. Milk samples were pack into the screw-type bottle and ash samples covered with zip lock covers.

\subsection{Extraction of milk samples}

$80 \mathrm{ml}$ of milk samples were mix with $150 \mathrm{ml}$ of acetone in the glass separating funnel. Then the samples were extracted with $40 \mathrm{ml}$ of hexane. The samples were settled, and the top layer passed through a $25 \mathrm{ml}$ of glass extraction column. Sample and sodium sulfate mixture was packed in an extraction column filled with $20 \mathrm{ml}$ of hexane and kept for 10 minutes. Then milk-hexane layer passed into the column. After washing the column, the total solvent has completely evaporated, and then sample vial has been measured for fat content

\subsection{Extraction of Ash sample}

Two grams of ash samples were weighed, and mixed with $20 \mathrm{ml}$ of $2 \mathrm{~N}$ of $\mathrm{HCl}$ was added. After one hour, $\mathrm{HCl}$-extract was washing with deionized water. The $\mathrm{pH}$ of the extract was checked and finally washed with methanol. The obtained $\mathrm{HCl}$ extract containing dioxin transferred into the sox let distillation unit. 250 $\mathrm{ml}$ of toluene was used for extraction for 16 hours.

Later on, $100 \mathrm{ml}$ of Dichloromethane (DCM) was mixed with $10 \mathrm{ml}$ of sample. The mixture was transferred into the liquid-liquid extraction column and extracted for $10 \mathrm{~min}$ for three times. Then the sample was condensed up to $20 \mathrm{ml}$ and further processed. After completing the extraction, the ash sample transferred into $30 \mathrm{ml}$ test tubes. The total $20 \mathrm{ml}$ of ash sample extract, added $4 \mathrm{~mL}$ into clean, dry test tubes, and then $20 \mu \mathrm{L}$ of nonene was mixed with each ash samples, then kept the samples in multi-solvent extraction unit for 20 mins.

\subsection{CALUX Bioassay}

The patented dioxin responsive mouse recombinant cell line, H1L6.1c2 was obtained from the Hiyoshi Corporation, Japan (Kumar \&Segen 2001) and the method developed by Xenobiotic Detection System (XDS, USA). The cleaned extract to concentrated and then passed through two columns, first with $25 \mathrm{ml}$ of acid silica column and second with $5 \mathrm{ml}$ of active carbon column. $5 \mathrm{ml}$ of the disposable column was 
packed with following materials, by glass wool, $0.3 \mathrm{cc}$ of sodium sulfate, $0.7 \mathrm{cc}$ of XCARB (1\%), which was an activated carbon patented by XDS (USA) and $0.6 \mathrm{cc}$ of sodium sulfate, rinsed with $5 \mathrm{ml}$ acetone, $10 \mathrm{ml}$ toluene and finally with $10 \mathrm{ml}$ of Hexane. A $10 \mathrm{ml}$ of the disposable column was filled from bottom to top, by glass wool, $1.0 \mathrm{cc}$ sodium sulfate, $4.3 \mathrm{cc}$ of $33 \%$ acid silica gel, and $1.0 \mathrm{cc}$ of sodium sulfate and rinsed with $30 \mathrm{ml}$ of Hexane. The acidic silica column placed on top of the carbon column. The fraction containing the Co-PCBs (PCB fraction) eluted with $15 \mathrm{ml}$ ethyl acetate/toluene/hexane (1:1:8) and the second fraction containing PCDD/F (dioxin fraction) was eluted afterwards with $20 \mathrm{ml}$ of toluene. Extracts were concentrated to dryness in a centrifuge under vacuum and reconstituted with $4 \mathrm{ml}$ of Hexane. The samples were stored at $4^{\circ} \mathrm{C}$ until analysis. Different concentration (lower to a higher level) of 2,3,7,8 - Tetrachloro dibenzo dioxin standard was prepared for the slope of calibrating the CALUX assay (9 point calibration) system (I-Chen Chou et al., 2008). The purified sample extracts in DMSO were suspended in a cell culture medium. Before dosing the plate, hexane solution was transferred into $4 \mu \mathrm{L}$ of DMSO under vacuum condition in the centrifuge, and finally, $400 \mu \mathrm{L}$ medium were added to each extract in DMSO. A 2, 3, 7, 8 TCDD standard curves were generated on each plate in addition to the samples. A mixed solution of PCDD/Fs was analyzed for quality control and DMSO alone was studied as blank. This

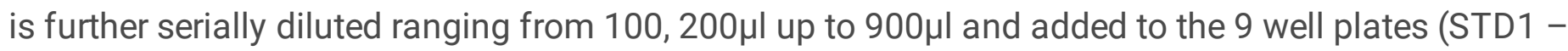
STD9). After 20-24 h of incubation, cells were examined microscopically for obvious toxicity. Each well rinsed with $50 \mu \mathrm{L}$ of phosphate-buffered saline (PBS), and $30 \mu \mathrm{L}$ of cell culture lysis reagent were added to each well then. The plate was shaken for $2 \mathrm{~min}$ at room temperature before being placed in the luminometer. After luciferase assay reagent, the light output was integrated and results were expressed in relative light unit $(R L U)$.

\section{Mechanism Of Calux Assay}

The recombinant cell line used in this assay $(\mathrm{H} 1 \mathrm{~L} 6.1 \mathrm{c} 2)$ was generated by stably transecting the plasmid pGudLuc6.1.This plasmid contains the CYP1A1 dioxin responsive domain. Polychlorinated diaromatic hydrocarbons (PCDH), bind to the AhR. The PCDH-AhR complex then travels to the nucleus of the cell. Activated PCDH-AhR then binds to specific sequences in the DNA called dioxin responsive elements (DRE).

The binding of the PCDH-AhR complex to the DRE will undergo transcription and produce transcripts altered by the founded dioxin. The resulted transcript will direct to luciferase synthesis. The messenger RNA (mRNA) then transfer to the cytoplasm for translation (protein synthesis). New proteins will be synthesized from the polypeptides, called luciferase enzyme. The synthesized protein can cause toxic effects. Dioxin TEQ was measured from luminescence produced by the luciferase reporter gene (Fig. 2). Addition of luciferin (substrate) results in the catabolism by luciferase enzyme, which produces the light measured by luminometer. The produced light was directly proportional to the evoked effects by PCDH.

\section{Results And Discussion}

\subsection{PCDD/Fs and DL-PCBs in bovine milk samples}


The concentrations of dioxin and dioxin-like compounds were analyzed by CALUX assay for both bovine milk samples. The concentration of dioxin in milk samples ranged from 0.028 to $7.331 \mathrm{pg}$ TEQ/g fat levels for 25 bovine milk samples, including one sample collected from Japan. Dioxins were contributing almost $83 \%$ to the total TEQ concentration. The total concentration of dioxins and DL- PCBs were showed in Table 1. The major source of dioxin exposure on humans was consuming contaminated animal source foods, like milk, egg, meat and fish. The European Union strictly regulated the presence of dioxin and DLPCBs in food sources to avoid human exposure. In such case, the maximum level of dioxins and DL-PCBs in milk and dairy products was 6.0pg TEQ/g fat. The maximum limit of PCDD/Fs in milk and milk products should be $3 \mathrm{pg}$ TEQ/g fat.

But in our study, the maximum value obtained was $7.331 \mathrm{pg}-\mathrm{TEQ} / \mathrm{g}$ fat levels, and the overall average level was $3.027 \mathrm{pg}$-TEQ/g fat, which infers that the values obtained from the current analysis revealed that the dioxin levels were very high compared to the values of Chou et al. (2008). The samples taken from Coimbatore rural, Chennai urban, Erode rural, Salem urban areas were higher than values reported by WHO (EU regulation). PCDD/Fs and DL-PCBs concentration were higher at $\mathrm{Cm}-\mathrm{R} 2$, among other sampling sites (Fig. 3). These values show an alarming situation to the farmers and consumers. Higher dioxins and DL-PCBs in rural areas may be due to the dumping of municipal wastes, pesticides, etc. Because, municipal wastes had been mostly dumped in the rural areas in most of the districts, which ultimately leads to higher dioxins contamination of rural areas. The present study was compared to dioxins concentration in pasteurized milk. Toxic equivalency of PCDD/Fs for pasteurized milk sample by CALUX assay was ranged between $0.012-0.748 \mathrm{pg}-\mathrm{TEQ} / \mathrm{g}$ fat levels and the overall average value was $0.246 \mathrm{pg}$ TEQ/g fat (Chou et al. 2008). The reported average value was relatively higher in the present study (1.976 pg TEQ/g) than PCDD/Fs in pasteurized milk samples. One more study reported the dioxins and DL-PCBs in pasteurized bovine milk by Monte Carlo simulation modelling. The mean dioxin and DLPCBs in pasteurized milk were $0.06+0.07 \mathrm{pg} \mathrm{WHO-TEQ/g}$ (Adekunte et al. 2010).

Many kinds of the literature showed the dioxin and DL-PCBs exposure on humans had been attributed by consumption $\mathrm{f}$ milk and dairy products. About $38 \%$ of the Dutch populations were affected by dioxins and DL-PCBs by consuming contaminated milk and milk products (Sapkota et al. 2007). The reason for dioxins and DL-PCBs in milk could be the feed that cow consuming, which influences the exceeding level than the EU-regulated level. Hoogenboom et al. (2010) reported cows feed (potato peels had kaolinic clay) containing high level of dioxins results in the huge contamination of milk. One study reveals that higher dioxins and DL-PCBs were observed in milk, due to grazing of the cow on contaminated pastures near to factories that produced PCBs (Turrio-Baldassarri et al. 2009). In some cases, cow consumption of roughage could lead to the presence of dioxins and DL-PCBs in milk because roughage was the predominant feed source for dairy cows. Further, ingestion of contaminated soil during grazing will also lead to milk contamination by dioxins (Rychen et al. 2008). Lactation period of cow helps to eliminate the dioxins and DL-PCBs through milk. Early lactation period of cow results in higher elimination of dioxins and DL-PCBs in milk fat, because cow utilizes the stored fat to balance their energy level. Additionally, dioxins and DL- PCBs are lipophilic; hence they accumulate in the body fat. Early lactation period will release the accumulated dioxins because the cows are in negative energy balance(Brambilla et al. 2008). 
Milk and dairy products from official control program carried out in Belgium showed a higher level of PCDD/Fs and DL-PCBs determined by HRMS/HRGC; the reported concentration was ranged from 1.58 to $1140.35 \mathrm{pg}$ bio-analytical equivalents (BEQ)/g fat (mean: $31.36 \mathrm{pg} \mathrm{BEQ/g}$ fat), respectively (Vromman et al. 2012). Similarly, few works of literature reported the mean concentration of dioxins and DL-PCBs in milk from different countries, like Italy (0.71 pg WHO TEQ/g; DL-PCBs: $1.39 \mathrm{pg}$ WHO TEQ/g) (Esposito et al. 2009, Fattore et al. 2006), China (0.03 pg WHO TEQ/g) (Li et al. 2007), and Belgium (1.57 + $0.71 \mathrm{pg}$ WHO TEQ/g; DL-PCBs:1.13 pg WHO TEQ/g) (Bilau et al. 2008, Windal et al. 2005). Milk samples from farms located in Brescia City were used to determine PCDD/Fs and DL-PCBs contamination level by highresolution mass spectrometry (HRMS), and the total WHO-TEQ values were ranged between $1.78-8.16 \mathrm{pg}$ WHO-TEQ/g fat (average: 4.13 pg WHO-TEQ/g fat), respectively. Higher DL-PCBs in the milk may be due to the steel industry, landfills and waste-energy plant and Caffaro factory (produced a higher volume of PCBs) vicinity to study area (Bertocchi et al. 2015). PCDD/Fs and DL-PCBs in milk had been measured from 115 milk collecting plants in France. The concentration rage of PCDD/Fs was $0.16-0.76 \mathrm{pg} T E Q / \mathrm{g}$ fat (median: $0.47 \mathrm{pg}$ TEQ/g fat) and DL-PCBs concentration was varied between $0.35-1.35 \mathrm{pg}$ TEQ/g fat (median: $0.47 \mathrm{pg} \mathrm{TEQ} / \mathrm{g}$ fat), respectively. The total concentration of dioxins and DL-PCBs were ranged from 0.60 to $1.77 \mathrm{pg}$ TEQ $/ \mathrm{g}$ fat $(0.78 \mathrm{pg}$ TEQ/g fat). DL-PCBs contribute about $62 \%$ to the total TEQ. Consumption of contaminated corn by dairy cows results in a higher level of dioxins and DL-PCBs in milk samples. The source for dioxins could be incineration of waste materials by scrap merchant (Durand et al. 2008).

Bovine milk from different countries showed the undulate contamination level of milk by various sources. Contamination level of PCDD/Fs and DL-PCBs in cow's milk from Austria was $0.14 \mathrm{pg}$ TEQ/g fat and $0.83 \mathrm{pg}$ TEQ/g fat; similarly, milk from German showed higher PCDD/Fs and DL-PCBs concentration (0.45 pg TEQ/g fat and $0.97 \mathrm{pg}$ TEQ/g fat) (Thanner \&Moche 2004). Schmid et al. (2003) reported the variation in dioxins and DL-PCBs contamination level based on origins, like a farm from a point source $(0.63+0.26 \mathrm{pg}$ TEQ/g fat $)$ and remote areas $(0.36+0.09 \mathrm{pg}$ TEQ/g fat). Milk samples from 63 farms in Italy were collected by personnel of Veterinary Authorities of Regional Sanitary Service (AASSLL) and determined the dioxins and DL-PCBs concentration by HRMS. Total PCDD/Fs and DL-PCBs concentration was ranged between 0.46 and $26.80 \mathrm{pg} / \mathrm{g}$ milk fat (mean: $3.06 \mathrm{pg} / \mathrm{g}$ milk fat). Some of the milk samples exceed dioxins contamination (above EU regulation limit), close to Napoli and Caserta districts, which contaminate the buffalo herd. Dioxin and DL-PCBs concentration did not exceed the EU regulation limit in the remaining 58 samples (Esposito et al. 2009). Another study also found bovine milk contamination collected from 50 farms in risk areas in 2008-2014 (Italy). The obtained result for dioxins and DL-PCBs ranged as $0.59-2.36$ WHO-TEQ pg/g fat, 0.70-1.14 WHO-TEQ pg/g fat and 0.25-2.75 WHO-TEQ pg/g fat for buffalo, bovine and sheep milk, respectively (Serpe et al. 2015). HRMS determined the concentration of dioxins and DL-PCBs in bovine and ovine milk. The sampling areas were close to incineration plant (Valpiana area and Casone area) in Tuscany, which leads to PCDD/Fs and DL-PCBs ranged from 0.71 to $2.9 \mathrm{pg}$ WHO-TEQ/g fat (Ingelido et al. 2009). However, the concentration range was not exceeded the EU regulation (PCDD/Fs: 3 pg WHO-TEQ/g fat and Total TEQs: 6 pg WHO-TEQ/g fat) and action levels (PCDD/Fs and DL-PCBs: 2 pg WHO-TEQ/g fat), respectively (Commission 2006). The 
incineration plants were processing municipal solid wastes at a large amount, which was the primary source for dioxins contamination to the surrounding area.

\subsection{PCDD/Fs and DL-PCBs in ash samples}

The concentration of PCDD/Fs and DL-PCBs in ash samples were ranged from 0.0129-1.208 ng TEQ/g (Table 2). According to WHO values, the results infer that concentration of PCDD/Fs and DL-PCBs were under safety levels (Fig. 4). Total dioxins and DL-PCBs concentration were higher in Erode-1 (1.2 ngTEQ/g) and Dindigul-1 (1.06 ng-TEQ/g) among other sampling locations. The major source for dioxins and dioxins related compounds the incineration of waste materials carried contamination. Incineration of many organic materials under less than optimal conditions leads to higher dioxins and related compounds release. In such a case, the higher level of dioxins in ash samples from Erode-1 and Dindigul1 illustrate the huge combustion of organic materials. Municipal solid waste incineration would be the point sources to release PCDD, PCDF and other toxicants; exposed by humans and other organisms (Davoli et al. 2010, Mari et al. 2009, Yang et al. 2006). Particle size also influences the dioxins concentration, fly ash generated from the municipal solid waste collected from major countries showed the dioxins concentration ranged from 0.47 to $25.74 \mathrm{ng} \mathrm{L-TEQ/g.} \mathrm{Fine} \mathrm{ash} \mathrm{particles} \mathrm{had} \mathrm{a} \mathrm{higher} \mathrm{level} \mathrm{of}$ dioxins than larger ash particles (Wu et al. 2016). Fly ash sample collected from sixteen municipal solid waste incinerators (MSWIs) in Taiwan results in 0.78-2.87 ng I-TEQ/g (average: $1.87 \mathrm{ng}$ I-TEQ/g) of dioxins. Further, higher chlorinated PCDDs were highly contributing than lower chlorinated PCDDs (Chang et al. 2011).

Cobo et al. (2009) reported dioxins and DL-PCBs in fly ash samples collected from incineration plant by high-resolution gas chromatography coupled to ion trap low-resolution mass spectrometry (HRGCQITMS/MS), which processing medical (blood, tissues, body parts, and contaminated sharps) and industrial wastes (polymerization sludge, expired food products, and commercial products). Higher PCDD/Fs (> $185 \mathrm{ng}$ WHO-TEQ/g) and lower DL-PCBs (1.2 ng WHO-EQ/g) concentration were found in the bag filter ash samples. This was corroborating with ESP ash samples (142.1 ng I-TEQ/g) collected from old and small- scale incinerator. Higher PCDD/Fs concentration in fly ash may occur due to old and inefficient operation of wastes (batch process, outdated furnace, slow gas cooling system). Composition of waste that incinerated also play an essential role in the dioxins in ash samples. Different types of ash samples were monitored for dioxins level, in such case types of ash samples from MSWls showed a different pattern of dioxin concentrations, such as bag filter ash (1.12 and $12.2 \mathrm{ng} \mathrm{I}-\mathrm{EQ} / \mathrm{g}$ ), gas scrubber ash (0.26 ng I-TEQ/g), electrostatic precipitators (ESP) (6.7, 8.5 and $142.1 \mathrm{ng} \mathrm{I-TEQ/g)} \mathrm{and} \mathrm{the} \mathrm{mixture} \mathrm{of}$ semi-dry and bag filter ash samples (0.97-1.5 ng l-EQ/g) (He et al. 2004, Yasuhara \&Katami 2007). Dioxin concentration in fly ash may vary depending on the specific operating parameters, like furnace type, capacity, furnace temperature and type of waste (Chang \&Chung 1998). Pan et al. (2013) reported the dioxins and DL-PCBs concentration in fly ash collected from 15 municipal concrete waste incinerator plants in different China cities. The concentration of PCDD/Fs and DL-PCBs in fly ash samples were ranged from 0.034 to $2.5 \mathrm{ng}-\mathrm{TEQ} / \mathrm{g}$, respectively. This was comparatively lower than dioxins reported in Taiwan (780-2860 ng TEQ/kg) (Chang et al. 2011), Zhejiang (China) (140-2680 ng TEQ/kg) (Chen et al. 2008), and 4 province in (Henan Province, Anhui Province, Jilin Province, Shandong Province and Hubei 
Province) China (0.0707-0.7742 ng I-TEQ/g) (Sun et al. 2017). The seasonal variation of dioxin distribution was studied by Sun et al., who discovered the increased dioxins concentration in Hubei Province during winter. Few more studies also found a higher level of dioxins in fly ash from MSWls in Shanghai, China $(7.53,1.52,0.98-1.5,4.16 \mathrm{ng}-\mathrm{TEQ} / \mathrm{g}$ (Shanghai) and 0.005-87 ng I-TEQ/g (He et al. 2004, Jin et al. 2003, Liu et al. 2015). The PCDD/Fs and DL-PCBs concentration was varied depending upon the particle size of the ash. Ash samples collected from MSWIs in China showed PCDD, PCDF and DL-PCBs concentration ranged from 0.19-2.27 ng I-TEQ/g, 0.2-4.9 ng I-TEQ/g and 0.02-0.22 ng I$\mathrm{TEQ} / \mathrm{g}$, respectively. Dioxins concentration was higher in fine ash particles (diameter $10-2.5$ and $<2.5$ ) than in the bulk ash (Wu et al. 2016). MSWI in southern Taiwan was studied to observe the dioxins and DL-PCBs level in fly ash. The reported dioxins concentration was ranged from $1.97 \times 10-3$ to $8.93 \times 10-$ $1 \mathrm{ng}$ I-TEQ/g (median: $4.52 \times 10-2 \mathrm{ng}$ I-TEQ/g) (Hsieh et al. 2018), ], this was corroborated with other countries including Taiwan (laboratory waste: $0.02-1.86 \mathrm{ng} \mathrm{I-TEQ/g),} \mathrm{and} \mathrm{Northeast} \mathrm{China} \mathrm{(fly} \mathrm{ash} \mathrm{from}$ MSWI: 3.2-800.1 ng I-TEQ/g), respectively (Li et al. 2016, Wu et al. 2014).

\section{Conclusion}

The concentration of PCDD/Fs and DL-PCBs was higher in Coimbatore rural and Chennai urban areas than the EU regulation level. This may vary due to consumption of contaminated feed and exposed to PCDD/Fs and DL-PCBs from the municipal dumping site. The samples were collected from cattle near dumping sites, which ultimately influenced the higher dioxin and DL-PCBs concentration in milk. Coimbatore rural, Chennai urban, Salem urban, and Erode rural areas were found higher PCDD/Fs and DLPCBs concentration in milk. Rural areas had been mostly used for dumping municipal solid waste dumping, which affects the nearby areas. Dioxins are lipophilic; hence it predominantly found in milk fat. In specific, early lactation period will release accumulated dioxins and related compounds at a higher level in milk.

Dioxins and DI-PCBs in ash samples were lower compared to EU regulation level. However, ash samples from Erode-1 and Dindigul-1 showed higher dioxin and DL-PCBs concentration among other sampling sites. Higher organic waste combustion results in a higher level of dioxins and related dioxin compounds in ash samples. Because dioxins are released into the fly ash during combustion, dioxins, and related compounds will affect the surrounding peoples and other species. Hence, further research is needed to better understand the human exposure of dioxins and dioxin related compounds by consuming contaminated milk and exposed to dioxins through inhalation. CALUX assay is a more rapid and costeffective method that can produce reliable data on dioxins contamination in environmental matrices.

\section{Declarations}

\section{Acknowledgement}

The authors sincerely thank to HIYOSHI Corporation (Japan), to provide facilities and support for the entire research work. A special thanks to Dr. R. Babu Rajendran (Department of Environmental 
Biotechnology, Bharathidasan University) providing this opportunity to accomplish the work in Japan.

\section{Author contribution}

Murugasamy Mayilsamy: investigation, data curation, validation and writing - original draft, Seethappan Sangeetha: investigation, data curation, validation and review, Masafumi Nakamura: method validation and investigation, Shunkei Ko: methodology, visualization and investigation, Muthusamy Govarthanan: visualization, investigation and formal analysis, Krishnamoorthi Vimalkumar: writing - review and editing, method validation and supervision.

\section{Funding}

This full work carried out and funded by Hiyoshi Corporation, Omihachiman, Shiga prefecture, Japan.

Availability of data and materials: All data generated or analyzed during this study are included in this published article.

Ethics approval and consent to participate: Not applicable

Consent for publication: Not applicable

Competing interests: The authors declare no competing interests.

\section{References}

Adekunte AO, Tiwari BK, O’Donnell CP (2010): Exposure assessment of dioxins and dioxin-like PCBs in pasteurised bovine milk using probabilistic modelling. Chemosphere 81, 509-516

Authority EFS (2012): Update of the monitoring of levels of dioxins and PCBs in food and feed. EFSA Journal 10, 2832

Bertocchi L, Ghidini S, Fedrizzi G, Lorenzi V (2015): Case-study and risk management of dioxins and PCBs bovine milk contaminations in a high industrialized area in Northern Italy. Environmental Science and Pollution Research 22, 9775-9785

Bilau M, Matthys C, Baeyens W, Bruckers L, De Backer G, Den Hond E, Keune H, Koppen G, Nelen V, Schoeters $G$ (2008): Dietary exposure to dioxin-like compounds in three age groups: results from the Flemish environment and health study. Chemosphere 70, 584-592

Bocio A, Domingo JL (2005): Daily intake of polychlorinated dibenzo-p-dioxins/polychlorinated dibenzofurans (PCDD/PCDFs) in foodstuffs consumed in Tarragona, Spain: a review of recent studies (2001-2003) on human PCDD/PCDF exposure through the diet. Environmental Research 97, 1-9

Brambilla G, Fochi I, Falce M, De Filippis SP, Ubaldi A, Di Domenico A (2008): PCDD and PCDF depletion in milk from dairy cows according to the herd metabolic scenario. Chemosphere 73, S216-S219 
Cancer IAfRo (1997): Polychlorinated dibenzo-para-dioxins and polychlorinated dibenzofurans. IARC monographs on the evaluation of carcinogenic risks to humans $69,228-238$

Chang M-B, Chung Y-T (1998): Dioxin contents in fly ashes of MSW incineration in Taiwan. Chemosphere 36, 1959-1968

Chang Y-M, Fan W-P, Dai W-C, Hsi H-C, Wu C-H, Chen C-H (2011): Characteristics of PCDD/F content in fly ash discharged from municipal solid waste incinerators. Journal of hazardous materials 192, 521-529

Chen T, Yan J, Lu S, Li X, Gu Y, Dai H, Ni M, Cen K (2008): Characteristic of polychlorinated dibenzo-pdioxins and dibenzofurans in fly ash from incinerators in China. Journal of Hazardous Materials 150, 510-514

Chou I-C, Lee W-J, Wang L-C, Chang-Chien G-P, Lee W-S, Lee H (2008): Validation of the CALUX bioassay as a screening and semi-quantitative method for PCDD/F levels in cow's milk. Journal of hazardous materials $154,1166-1172$

Cobo M, Gálvez A, Conesa JA, de Correa CM (2009): Characterization of fly ash from a hazardous waste incinerator in Medellin, Colombia. Journal of hazardous materials 168, 1223-1232

Commission E (2006): Commission Regulation of 19 December 2006 setting maximum levels for certain contaminants in foodstuffs, 1881/2006/EC. Official Journal

Davoli E, Fattore E, Paiano V, Colombo A, Palmiotto M, Rossi A, Grande MI, Fanelli R (2010): Waste management health risk assessment: A case study of a solid waste landfill in South Italy. Waste Management 30, 1608-1613

Durand B, Dufour B, Fraisse D, Defour S, Duhem K, Le-Barillec K (2008): Levels of PCDDs, PCDFs and dioxin-like PCBs in raw cow's milk collected in France in 2006. Chemosphere 70, 689-693

Esposito M, Cavallo S, Serpe F, D’Ambrosio R, Gallo P, Colarusso G, Pellicanò R, Baldi L, Guarino A, Serpe L (2009): Levels and congener profiles of polychlorinated dibenzo-p-dioxins, polychlorinated dibenzofurans and dioxin-like polychlorinated biphenyls in cow's milk collected in Campania, Italy. Chemosphere 77, $1212-1216$

Esposito M, Serpe F, Cavallo S, Pellicanò R, Gallo P, Colarusso G, D'ambrosio R, Baldi L, lovane G, Serpe L (2010): A survey of dioxins (PCDDs and PCDFs) and dioxin-like PCBs in sheep and goat milk from Campania, Italy. Food Additives and Contaminants: Part B 3, 58-63

Fattore E, Fanelli R, Turrini A, Di Domenico A (2006): Current dietary exposure to polychlorodibenzo-pdioxins, polychlorodibenzofurans, and dioxin-like polychlorobiphenyls in Italy. Molecular nutrition \& food research 50, 915-921 
Han D, Nagy SR, Denison MS (2004): Comparison of recombinant cell bioassays for the detection of Ah receptor agonists. Biofactors 20,11-22

He P-J, Zhang H, Zhang C-G, Lee D-J (2004): Characteristics of air pollution control residues of MSW incineration plant in Shanghai. Journal of hazardous materials 116, 229-237

Hoogenboom R, Bovee T, Traag W, Hoogerbrugge R, Baumann B, Portier L, van de Weg G, de Vries J (2006): The use of the DR CALUX® bioassay and indicator polychlorinated biphenyls for screening of elevated levels of dioxins and dioxin-like polychlorinated biphenyls in eel. Molecular nutrition \& food research 50, 945-957

Hoogenboom R, Zeilmaker M, van Eijkeren J, Kan K, Mengelers M, Luykx D, Traag W (2010): Kaolinic clay derived PCDD/Fs in the feed chain from a sorting process for potatoes. Chemosphere 78, 99-105

Hsieh Y-K, Chen W-S, Zhu J, Wu Y-J, Huang Q (2018): Health risk assessment and correlation analysis on PCDD/FS in the fly ash from a municipal solid waste incineration plant. Aerosol Air Qual. Res 18, 734-748

Ingelido AM, Abballe A, Di Domenico A, Fochi I, lacovella N, Saragosa A, Spagnesi M, Valentini S, De Felip E (2009): Levels and profiles of polychlorinated dibenzo-p-dioxins, polychlorinated dibenzofurans, and polychlorinated biphenyls in feedstuffs and milk from farms in the vicinity of incineration plants in Tuscany, Italy. Archives of environmental contamination and toxicology 57, 397-404

Jin Y, Tian H, Nie Y, Yin H, Hai Y, Chen Z (2003): Dioxins contents in fly ash of MSW incinerator in three city. Huan jing ke xue= Huanjing kexue 24, 21-25

Kiviranta H, Ovaskainen M-L, Vartiainen T (2004): Market basket study on dietary intake of PCDD/Fs, PCBs, and PBDEs in Finland. Environment international 30, 923-932

Kumar S, Segen J (2001): Gesture-based computer interface. Google Patents

Lauby-Secretan B, Loomis D, Grosse Y, El Ghissassi F, Bouvard V, Benbrahim-Tallaa L, Guha N, Baan R, Mattock H, Straif K (2013): Carcinogenicity of polychlorinated biphenyls and polybrominated biphenyls. Lancet Oncology 14, 287-288

Li J-G, Wu Y-N, Zhang L, Zhao Y-F (2007): Dietary intake of polychlorinated dioxins, furans and dioxin-like polychlorinated biphenyls from foods of animal origin in China. Food additives and contaminants 24 , 186-193

Li J, Dong H, Sun J, Nie J, Zhang S, Tang J, Chen Z (2016): Composition profiles and health risk of PCDD/F in outdoor air and fly ash from municipal solid waste incineration and adjacent villages in East China. Science of The Total Environment 571, 876-882

Liu G, Jiang X, Wang M, Dong S, Zheng M (2015): Comparison of PCDD/F levels and profiles in fly ash samples from multiple industrial thermal sources. Chemosphere 133, 68-74

Page 12/19 
Mari M, Nadal M, Schuhmacher M, Domingo JL (2009): Exposure to heavy metals and PCDD/Fs by the population living in the vicinity of a hazardous waste landfill in Catalonia, Spain: Health risk assessment. Environment international 35, 1034-1039

Pan Y, Yang L, Zhou J, Liu J, Qian G, Ohtsuka N, Motegi M, Oh K, Hosono S (2013): Characteristics of dioxins content in fly ash from municipal solid waste incinerators in China. Chemosphere 92, 765-771

Rychen G, Jurjanz S, Toussaint H, Feidt C (2008): Dairy ruminant exposure to persistent organic pollutants and excretion to milk. Animal: an international journal of animal bioscience 2, 312

Sapkota AR, Lefferts LY, McKenzie S, Walker P (2007): What do we feed to food-production animals? A review of animal feed ingredients and their potential impacts on human health. Environmental health perspectives $115,663-670$

Schmid P, Gujer E, Zennegg M, Studer C (2003): Temporal and local trends of PCDD/F levels in cow's milk in Switzerland. Chemosphere 53, 129-136

Serpe FP, Scaramuzzo A, Maglio P, Lambiase S, Esposito M (2015): Monitoring plan on PCDD/Fs and DLPCBs milk contamination in Campania region (Italy). International Journal of Analytical Mass Spectrometry and Chromatography 3, 32

Sun J, Hu J, Zhu G, Zhang D, Zhu Y, Chen Z, Li J, Zhang H, Tang J, Nie J (2017): PCDD/Fs distribution characteristics and health risk assessment in fly ash discharged from MSWIs in China. Ecotoxicology and environmental safety $139,83-88$

Thanner G, Moche W (2004): PCDD/F and PCB levels in Austrian cow's milk. Organohal. Comp 66, 21032106

Turrio-Baldassarri L, Alivernini S, Carasi S, Casella M, Fuselli S, lacovella N, lamiceli AL, La Rocca C, Scarcella C, Battistelli CL (2009): PCB, PCDD and PCDF contamination of food of animal origin as the effect of soil pollution and the cause of human exposure in Brescia. Chemosphere 76, 278-285

Vromman V, Baert K, Vanderperren H, Goeyens L, Huyghebaert A, Maghuin-Rogister G, Scippo M-L, Moons E, Vinkx C, Saegerman C (2012): Evaluation of the use of CALUX results for dioxins and dioxin-like PCBs analysis for quantitative human exposure assessments. Food Control 27, 314-321

Warner M, Eskenazi B, Patterson DG, Clark G, Turner WE, Bonsignore L, Mocarelli P, Gerthoux PM (2005): Dioxin-Like TEQ of women from the Seveso, Italy area by ID-HRGC/HRMS and CALUX. Journal of Exposure Science \& Environmental Epidemiology 15, 310-318

Windal I, Van Wouwe N, Eppe G, Xhrouet C, Debacker V, Baeyens W, De Pauw E, Goeyens L (2005): Validation and interpretation of CALUX as a tool for the estimation of dioxin-like activity in marine biological matrixes. Environmental science \& technology 39, 1741-1748 
Wu J-L, Lin T-C, Wang Y-F, Wang J-W, Wang C-T, Kuo Y-M (2014): Polychlorinated dibenzo-p-dioxin and dibenzofuran (PCDD/F) emission behavior during incineration of laboratory waste. Part 1: Emission profiles obtained using chemical assay and bioassay. Aerosol and Air Quality Research 14, 1199-1205

Wu S, Zhou J, Pan Y, Zhang J, Zhang L, Ohtsuka N, Motegi M, Yonemochi S, Oh K, Hosono S (2016): Dioxin distribution characteristics and health risk assessment in different size particles of fly ash from MSWIs in China. Waste Management 50, 113-120

Yang M, Park MS, Lee HS (2006): Endocrine disrupting chemicals: human exposure and health risks. Journal of Environmental Science and Health Part C 24, 183-224

Yasuhara A, Katami T (2007): Leaching behavior of polychlorinated dibenzo-p-dioxins and furans from the fly ash and bottom ash of a municipal solid waste incinerator. Waste management $27,439-447$

\section{Tables}

Table 1 CALUX Assay result for bovine milk samples 


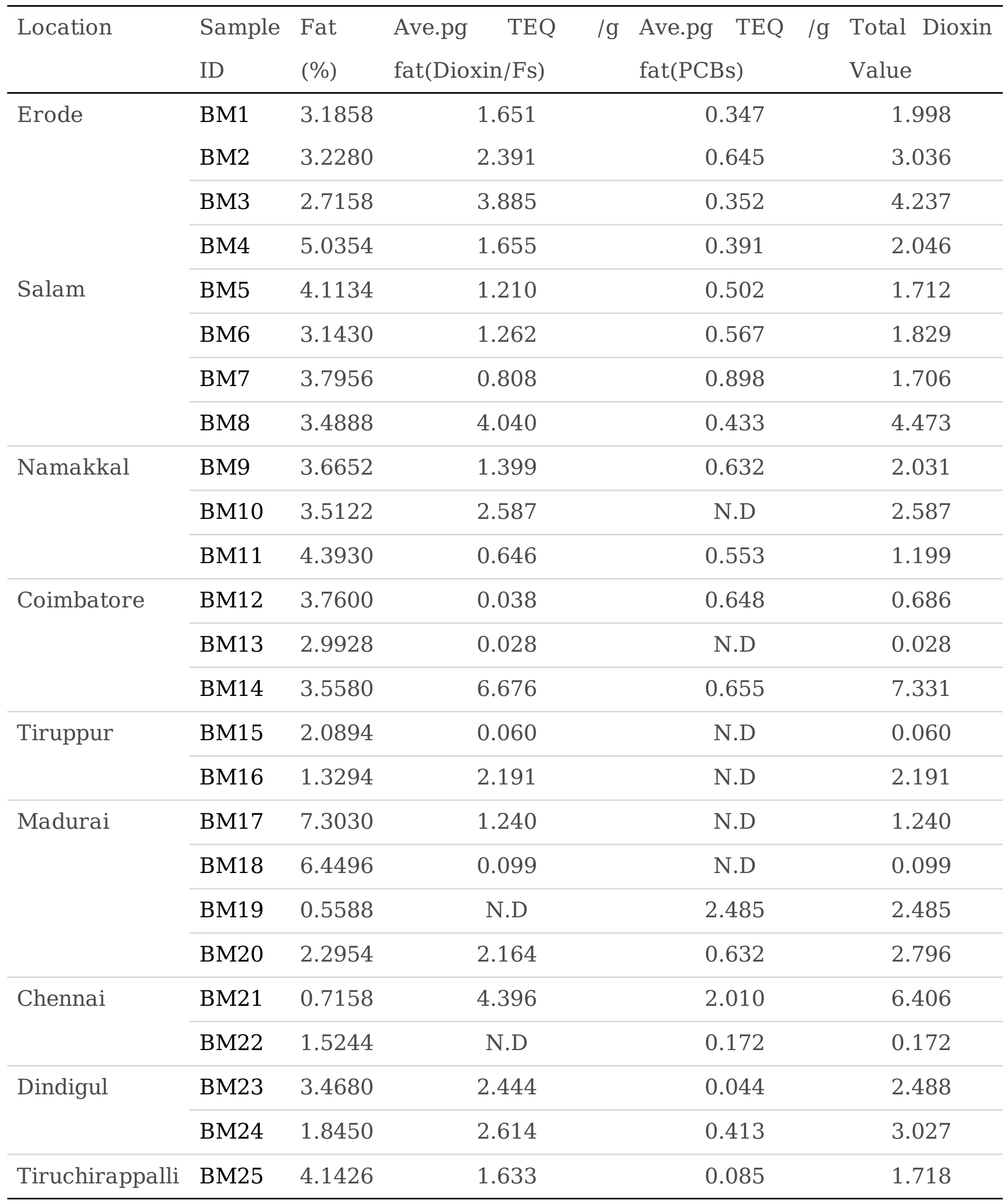

ND-not detected, U-Urban, R-Rural 
Table.2: CALUX Assay result for ash samples

\begin{tabular}{|c|c|c|c|c|}
\hline Sample Name & Sample ID & ng TEQ/g (Dioxin/Fs) & ng TEQ/g (PCB) & Total Dioxin Value \\
\hline \multirow[t]{2}{*}{ Salam } & AS1 & 0.0714 & 0.0443 & 0.1157 \\
\hline & AS2 & 0.0081 & 0.0048 & 0.0129 \\
\hline \multirow[t]{2}{*}{ Erode } & AS3 & 1.2009 & 0.0071 & 1.208 \\
\hline & AS4 & 0.4909 & 0.0057 & 0.4966 \\
\hline \multirow[t]{2}{*}{ Namakkal } & AS5 & 0.0834 & 0.0081 & 0.0915 \\
\hline & AS6 & 0.1219 & 0.0039 & 0.1258 \\
\hline \multirow[t]{2}{*}{ Cuddalore } & AS7 & 0.0032 & N.D & 0.0032 \\
\hline & AS8 & 0.0039 & 0.0167 & 0.0206 \\
\hline \multirow[t]{2}{*}{ Chennai } & AS9 & 0.1043 & 0.0119 & 0.1162 \\
\hline & AS10 & 0.0892 & N.D & 0.0892 \\
\hline \multirow[t]{3}{*}{ Dindigul } & AS11 & 1.0637 & 0.0038 & 1.0675 \\
\hline & AS12 & 0.0803 & 0.0006 & 0.0809 \\
\hline & AS13 & 0.0091 & 0.0122 & 0.0213 \\
\hline \multirow[t]{3}{*}{ Madurai } & AS14 & 0.2559 & N.D & 0.2559 \\
\hline & AS15 & 0.0466 & N.D & 0.0466 \\
\hline & AS16 & 0.0593 & 0.0091 & 0.0684 \\
\hline
\end{tabular}

ND-not detected

Figures 


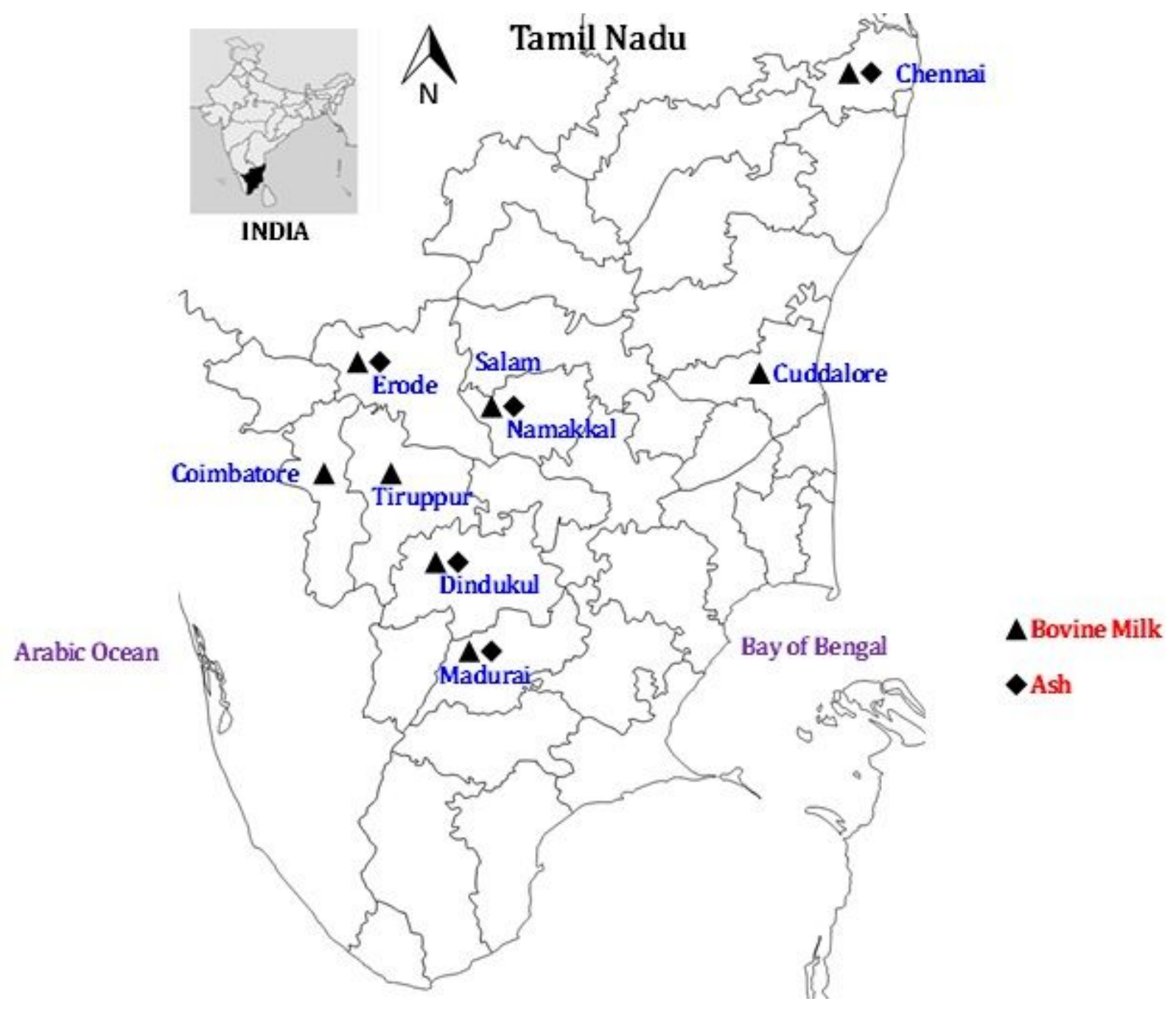

Figure 1

Bovine milk and Ash samples location of south Indian region

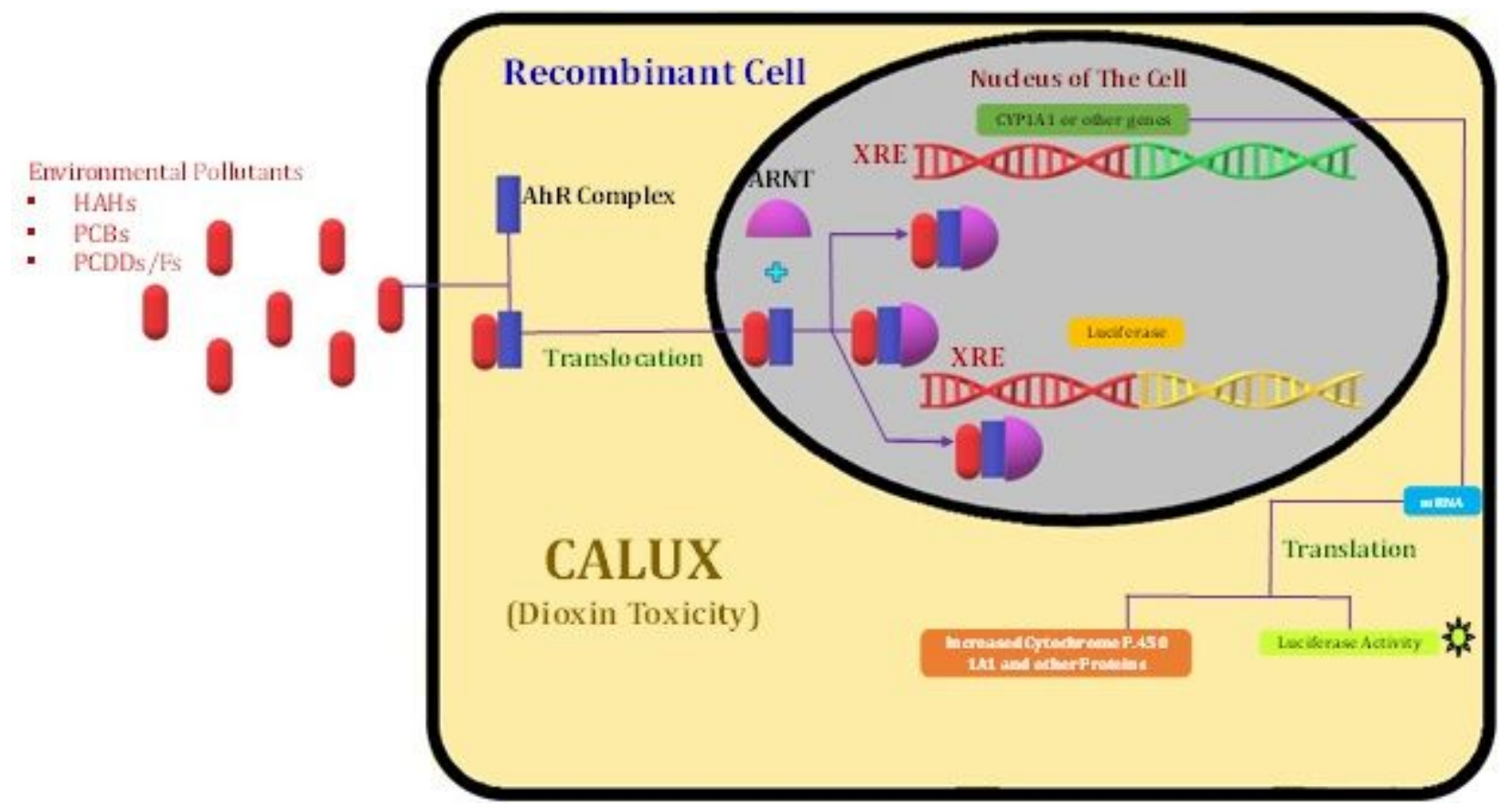


Figure 2

Mechanism of CALUX Assay (Hiyoshi Corporation, Japan), AhR - Aryl hydrocarbon Receptor, ARNT AhR Nuclear Translocator protein, XRE - Dioxin(X) Responsive Element

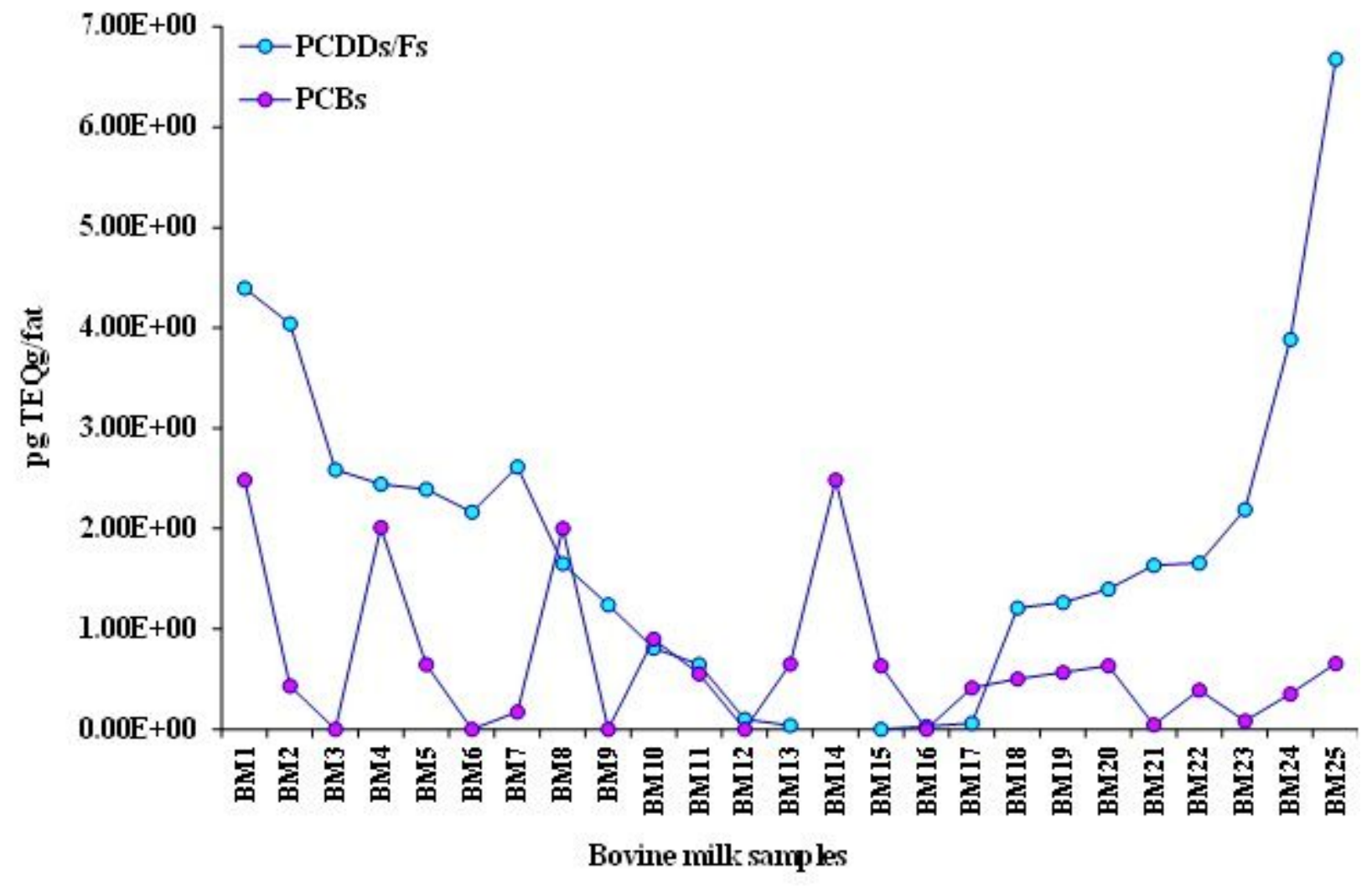

Figure 3

Analysis of Total dioxin from bovine milk samples with using CALUX Assay. Concentration levels were measured by $\mathrm{pg} \mathrm{TEQ} / \mathrm{g}$ fat

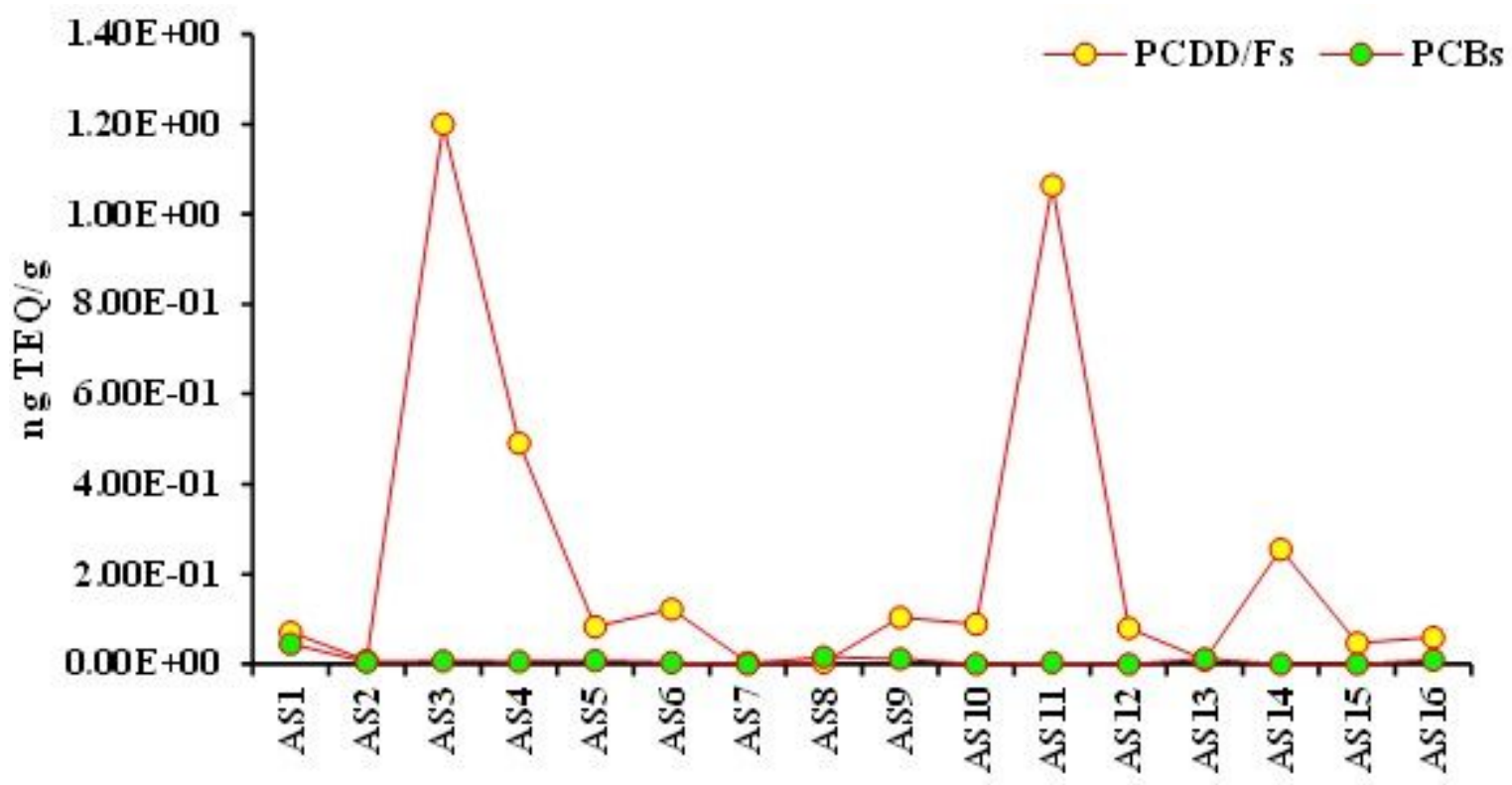

Ash samples 
Figure 4

Analysis of total dioxin from ash samples with using CALUX Assay. Concentration levels were measured by $\mathrm{ng} \mathrm{TEQ} / \mathrm{g}$

\section{Supplementary Files}

This is a list of supplementary files associated with this preprint. Click to download.

- GraphicalAbstract.jpg 